\title{
Intracellular Potassium Activity in Guinea Pig Papillary Muscle during Prolonged Hypoxia
}

\author{
Thomas Guarnieri and Harold C. Strauss, Departments of Medicine and \\ Pharmacology, Duke University Medical Center, Durham, \\ North Carolina 27710
}

A B S T R A C T During prolonged hypoxia, intracellular potassium concentration, $[\mathrm{K}]_{\mathrm{i}}$ has been reported to fall by $70 \%$ with a concomitant decrease in the calculated potassium equilibrium potential, $E_{\mathbf{k}}$. Nevertheless, resting membrane potential, $\mathrm{V}_{\mathrm{m}}$, declined only slightly. Because $V_{m}$ depolarized very little in relation to the calculated $\mathrm{E}_{\mathbf{K}}$, it was hypothesized that electrogenic $\mathrm{Na}-\mathrm{K}$ pumping contributed up to $40 \mathrm{mV}$ to $\mathrm{V}_{\mathrm{m}}$ during prolonged hypoxia. To further test this hypothesis we studied what changes prolonged hypoxia makes in the thermodynamically active fraction of cellular potassium, intracellular potassium activity, $\alpha_{\mathrm{k}}^{\mathrm{i}}$, and how change in $\alpha_{\mathrm{k}}^{\mathrm{i}}$ affects the relationship between $V_{m}, E_{K}$ and, by inference, the $\mathrm{Na}-\mathrm{K}$ pump. Using double-barrel $\mathrm{K}$-selective electrodes, $\mathrm{V}_{\mathrm{m}}$ and $\alpha_{\mathrm{K}}^{\mathrm{i}}$ were measured in quiescent guinea pig right ventricular papillary muscles superfused for $8 \mathrm{~h}$ with hypoxic Tyrode's solution. Over the 8 -h period both $V_{m}$ and $\alpha_{k}^{i}$ decreased. However, the decline in $V_{m}$ was paralleled by a decrease in the $E_{K}$ calculated from $\alpha_{k}^{i}$. At no time was there hyperpolarization of $V_{m}$ beyond $E_{k}$.

After $8 \mathrm{~h}$ the $\mathrm{Na}-\mathrm{K}$ pump was inhibited by exposing the muscles to $0.1 \mathrm{mM}$ ouabain. The onset of an increase in extracellular potassium activity, measured with a double-barrel electrode, was used to mark the amount of depolarization of $\mathrm{V}_{\mathrm{m}}$ due solely to pump inhibition. After hypoxia, $V_{m}$ depolarized $8.4 \pm 4.4 \mathrm{mV}$ before extracellular potassium activity $\left(\alpha_{\mathbf{k}}^{\mathbf{e}}\right)$ increased. Thus, the decrease in $\alpha_{\mathrm{k}}^{\mathrm{i}}$ during hypoxia is much less than that reported for $[K]_{i}$. The parallel decline in $V_{m}$ and $E_{k}$ and the small depolarization of $V_{m}$ with ouabain suggest that after prolonged hypoxia the $\mathrm{Na}-\mathrm{K}$ pump continues to contribute to $V_{m}$, but the amount of this contribution is substantially less than previously reported.

Address correspondence to Dr. Guarnieri.

Received for publication 11 May 1981 and in revised form 15 September 1981.

\section{INTRODUCTION}

Hypoxia causes characteristic changes in the transmembrane action potential of ventricular muscle. Several investigators reported a shortening of the plateau and a reduction in the overshoot, both alterations occurring in the face of minimal change in the resting potential $\left(V_{m}\right)^{1}(1-3)$. One observation, nevertheless, remains enigmatic. McDonald and MacLeod $(4,5)$ exposed ventricular muscle to hypoxia for $8 \mathrm{~h}$ and confirmed the lack of change in $V_{m}$ during this time period. They also reported that at the end of the 8-h period, intracellular potassium concentration $\left([\mathrm{K}]_{\mathrm{i}}\right)$ decreased dramatically, and from the measured potassium concentration they calculated that the potassium equilibrium potential decreased from $-82 \mathrm{mV}$ to -47 $\mathrm{mV}$. Since the measured $\mathrm{V}_{\mathrm{m}}$ remained at $-80 \mathrm{mV}$, it appeared that during prolonged hypoxia there was sustained hyperpolarization of $\mathrm{V}_{\mathrm{m}}$ beyond the potassium equilibrium potential $\left(E_{K}\right)$ in excess of $30 \mathrm{mV}$. They attributed this deviation of $V_{m}$ from $E_{K}$ to increased electrogenic $\mathrm{Na}-\mathrm{K}$ pumping and hypothesized that the electrogenic $\mathrm{Na}-\mathrm{K}$ pump, in large measure, maintains $V_{m}$ during prolonged hypoxia $(4,5)$.

Several studies have demonstrated that when the electrogenic sodium pump is stimulated, $\mathrm{V}_{\mathrm{m}}$ can transiently exceed $E_{K}(6-8)$. In an experiment representative of non-steady-state behavior after a period of sodium loading, Page and Storm (6) observed transient

\footnotetext{
${ }^{1}$ Abbreviations used in this paper: $\alpha_{\mathrm{K}}^{\mathrm{e}}$, extracellular potassium activity; $\alpha_{\mathrm{K}}^{\mathrm{i}}$, intracellular potassium activity; $\alpha_{\mathrm{K}}^{\circ}$, superfusate potassium activity; $\alpha_{\mathrm{Na}}^{\mathrm{i}}$, intracellular sodium activity; $\alpha_{\mathrm{Na}}^{\circ}$, superfusate sodium activity; $\mathrm{APD}_{50}$, action potential duration at $50 \%$ repolarization; $E_{K}$, potassium equilibrium potential; $\gamma \mathrm{K}, \mathrm{K}^{+}$activity coefficient; $\mathrm{K}_{\mathrm{KN}_{\text {a }}}$, selectivity coefficient; $[\mathrm{K}]_{\mathrm{i}}$, intracellular potassium concentration; OS, overshoot; $V_{m}$, resting membrane potential; $V_{K}^{o}$, potassium electrode reading in superfusate; $V_{m}^{\circ}$, reference electrode reading in superfusate; $V_{K}^{e}$, potassium electrode reading in extracellular space; $V_{k}^{i}$, potassium electrode reading in intracellular space.
} 
hyperpolarization of $V_{m}$ beyond $E_{K}$ of $6 \mathrm{mV}$ when papillary muscle recovered from prior incubation in cold, potassium-free perfusate. As summarized by Thomas and others $(9,10)$, this type of hyperpolarization must be temporary, because the change in the electrochemical driving force for the passive movement of potassium $\left(V_{m}-E_{K}\right)$ favors a redistribution of potassium across the cell membrane. This redistribution of potassium in turn drives $\mathrm{E}_{\mathrm{K}}$ to more negative values, which continue to approach $\mathrm{V}_{\mathrm{m}}$. Thus the observation that there was sustained deviation of the measured $\mathrm{V}_{\mathrm{m}}$ from the calculated $\mathrm{E}_{\mathrm{K}}$ during prolonged hypoxia described by McDonald and MacLeod remains problematic.

Potassium ion-selective electrodes can determine the thermodynamically active fraction of cellular potassium, intracellular potassium activity $\left(\alpha_{\mathbf{k}}^{\mathbf{i}}\right)(11-13)$. These electrodes avoid the potential pitfalls of measuring total potassium concentration in whole muscle bundles, particularly bundles exposed to the insult of hypoxia. Moreover, they are capable of monitoring changes in $\alpha_{\mathrm{k}}^{\mathrm{i}}$ in a given cell over time. Consequently, potassium-selective electrodes were used to investigate the hypothesis that the $\mathrm{Na}-\mathrm{K}$ pump maintains $\mathrm{V}_{\mathrm{m}}$ during prolonged hypoxia. We studied the changes that severe hypoxia causes in $\alpha_{\mathrm{K}}^{\mathrm{i}}$ and how these changes affect the relationship between $V_{m}, E_{K}$ and, by inference, the Na-K pump.

To further investigate what role the pump plays in maintaining $\mathrm{V}_{\mathrm{m}}$ during prolonged hypoxia, additional corroborative experiments were performed. During ouabain inhibition of the Na-K pump in both normoxic and hypoxic muscles the onset of an increase in extracellular potassium activity, $\alpha_{\mathbf{k}}^{\mathrm{e}}$, was used to mark the upper limit of the amount of depolarization due solely to pump inhibition (14). We used this amount of depolarization as another index of pump contribution to $\mathrm{V}_{\mathrm{m}}$.

\section{METHODS}

Hartley guinea pigs (Camm Research Lab Animals, Wayne, $\mathrm{N}$. J.) weighing $250-400 \mathrm{~g}$ were sacrificed by a blow to the base of the skull. Right ventricular papillary muscles were dissected and immersed in Tyrode's solution. Only muscles having diameters $<0.5 \mathrm{~mm}$ were used.

Muscles were superfused in a Gadsby (15) fast-flow perfusion bath $(4 \mathrm{~mm} \times 10 \mathrm{~mm} \times 15 \mathrm{~mm})$ with either normoxic or hypoxic Tyrode's solution of the following composition in $\mathrm{mM}$ : $\mathrm{NaCl}, 135.4 ; \mathrm{KCl}, 4.0 ; \mathrm{NaH}_{2} \mathrm{PO}_{2}, 1.8 ; \mathrm{CaCl}_{2}, 2.7$; $\mathrm{MgCl}_{2}, 0.5 ; \mathrm{NaHCO}_{3}, 18.0$; and dextrose, 5.5. With this concentration of potassium the activity of the bulk potassium $\left(\alpha_{\mathrm{k}}^{\circ}\right)$ is $\sim 3.0 \mathrm{mM}(16)$. Normoxic solutions were bubbled with $95 \% \mathrm{O}_{2}$ and $5 \% \mathrm{CO}_{2}$. Solutions were made hypoxic by bubbling with $95 \% \mathrm{~N}_{2}$ and $5 \% \mathrm{CO}_{2}$ in a glass reservoir with a one-way valve and by using a glass-enclosed perfusion system. During hypoxia the partial pressure of oxygen sampled near the muscle was $11.4 \pm 1.3 \mathrm{~mm} \mathrm{Hg}$. Temperature was $33^{\circ}-34^{\circ} \mathrm{C}$ and bath flow was $10-11 \mathrm{ml} / \mathrm{min}$.
The transmembrane action potential was simultaneously displayed on a Tektronix 5103 oscilloscope (Tektronix, Inc., Beeverton, Oreg.) and a Gould 2400 strip chart recorder (Gould Instruments Div., Inc., Cleveland, Ohio). The oscilloscope signals were photographed with a high-speed Grass Kymograph camera (Grass Instrument Co., Quincy, Mass.) for later determination of overshoot (OS) and action potential duration at $50 \%$ repolarization $\left(A P D_{50}\right)$. The latter was obtained by digitizing the magnified image of an action potential photograph using a SAC GP-3 graph pen digitizer (Science Accessories Corp., Southport, Conn.) interfaced with a DECLab PDP 11/03 computer (Digital Equipment Corp., Marboro, Mass.).

Ion-selective electrodes. Intracellular and extracellular potassium activities were measured with single- and doublebarrel liquid ion exchanger microelectrodes as previously described (17-19). In the double-barrel electrodes the reference barrel was filled with $1.0 \mathrm{M} \mathrm{NaCl}$. The barrel that contained the potassium-selective resin (Corning resin 477317; Corning Medical, Medfield, Mass.), was filled with $0.5 \mathrm{M}$ $\mathrm{KCl}$. Electrodes were calibrated according to the method of Walker and Brown (20), where the electrode's response in pure potassium solutions is compared to its response in the superfusate, Tyrode's solution (Fig. 1). This generates a value, $\alpha$ selectivity, which is given by the following formula: $\alpha$ selectivity $=\alpha \mathrm{K}_{\text {Tyrode }}+\mathrm{K}_{\mathrm{KNa}} \alpha \mathrm{Na}_{\text {Tyrode }}$. The selectivity, $\mathrm{K}_{\mathrm{KNa}}$, obtained from this expression was $>50 / 1$ potassium over sodium. As can be seen from Fig. 1, the electrode's response to pure potassium chloride was linear between $1,000 \mathrm{mM}$ and $1 \mathrm{mM}$, and produced slopes of $>50 \mathrm{mV} /$

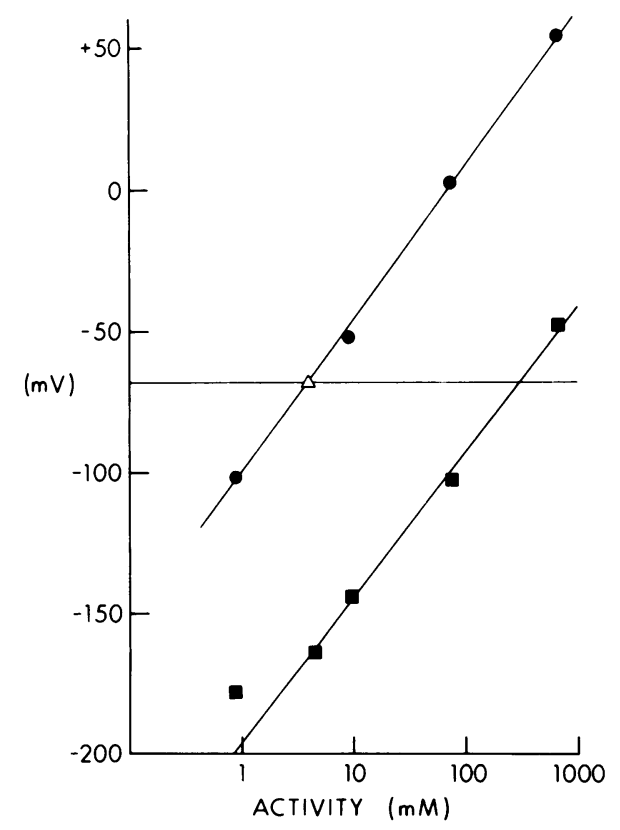

FIgURE 1 Calibration curve. Selectivity is calculated by comparing the response of the electrode in pure $\mathrm{KCl}$ solution $(\bullet)$ with the response in Tyrode's solution $(\Delta)$, where total activity $=\alpha \mathrm{K}_{\mathrm{Tyrode}}+\mathrm{K}_{\mathrm{KNa}} \alpha \mathrm{Na}_{\text {Tyrode }}$. Selectivity was greater than $50 / 1$ over sodium. Also shown is the electrode's response to pure $\mathrm{NaCl}$ solution $(\square)$, which is linear between $5 \mathrm{mM}$ and $1,000 \mathrm{mM}$, but which tends to be nonlinear at $\mathrm{Na}$ concentrations, less than $\sim 1-5 \mathrm{mM}$. 
decade change in potassium activity. In solutions of pure sodium chloride, the electrode's response tended to be nonlinear at sodium concentrations less than $\sim 1 \mathrm{mM}$, which would not interfere with measuring changes in $\alpha_{\mathrm{k}}^{\mathrm{i}}$. The minimal detectable change in potassium concentration against a background concentration of $150 \mathrm{mM}$ was $1.5 \mathrm{mM}$. Potassium activity was calculated by the following derivation of the Nikolskii equation (21), which we have previously reported $(17,18)$

$\alpha_{\mathrm{K}}^{\mathrm{x}}=\left(\alpha_{\mathrm{K}}^{\mathrm{o}}+\mathrm{K}_{\mathrm{KNa}} \alpha_{\mathrm{Na}}^{\circ}\right) \exp \left\{\frac{2.303}{\mathrm{~S}}\right.$

$$
\left.\times\left[\left(\mathbf{V}_{\mathbf{k}}^{\mathbf{x}}-\mathbf{V}_{\mathbf{k}}^{o}\right)-\left(\mathbf{V}_{\mathbf{m}}^{\mathbf{x}}-\mathbf{V}_{\mathbf{m}}^{o}\right)\right]\right\}-\mathbf{K}_{\mathbf{K N a}} \alpha_{\mathrm{Na}}^{\mathbf{i}},
$$

where

$$
\begin{aligned}
& \alpha_{\mathrm{K}}^{\mathrm{x}}=\alpha_{\mathrm{K}}^{\mathrm{e}} \text { (extracellular potassium activity) or } \alpha_{\mathrm{K}}^{\mathrm{i}} \\
& \text { (intracellular activity) } \\
& \alpha_{\mathrm{Na}}^{\mathrm{i}}=\text { intracellular sodium activity } \\
& \alpha_{\mathbf{K}}^{\circ}=\text { superfusate potassium activity } \\
& \alpha_{\mathrm{Na}}^{\mathrm{o}}=\text { superfusate sodium activity } \\
& \mathrm{K}_{\mathrm{KNa}_{\mathrm{a}}}=\text { selectivity coefficient } \\
& \mathrm{S}=\text { slope } \\
& V_{\mathbf{K}}^{\mathrm{x}}=\mathrm{V}_{\mathbf{K}}^{\mathrm{e}} \text { (K electrode reading in the extracellular space) } \\
& \text { or } V_{K}^{i} \text { ( } K \text { electrode reading in the intracellular space) } \\
& V_{K}^{o}=K \text { electrode reading in the superfusate }
\end{aligned}
$$

Tip resistance ranged between $10^{9}-10^{10} \Omega$. In $\alpha_{\mathrm{K}}^{\mathrm{i}}$ determinations, $\mathrm{K}_{\mathrm{KNa}} \alpha_{\mathrm{Na}}^{\mathrm{i}}$ was neglected because its value is $<0.1 \mathrm{mM}$.

Protocols. Muscles were quiescent in all protocols except for impalement verification. In the first set of experiments, muscles were switched to hypoxic perfusate for $3 \mathrm{~h}$ during which multiple impalements with single-barrel potassiumselective electrodes and conventional $3 \mathrm{M} \mathrm{KCl}$ electrodes were made every $30 \mathrm{~min}$. Each determination of $\alpha_{\mathrm{K}}^{\mathrm{i}}$ consisted of the average of between three and six separate $V_{m}$ and $V_{K}$ measurements. Browning and Strauss (17) have shown that this technique of multiple impalements is important in determining $\alpha_{\mathrm{K}}^{\mathrm{i}}$ because of the wide variation in the range of values of $\alpha_{\mathrm{k}}^{\mathrm{i}}$.

In the second protocol the duration of hypoxia was extended to $8 \mathrm{~h}$, similar to the protocol used by McDonald and MacLeod $(4,5)$. In these experiments a single impalement with a double-barrel electrode was made during the control period and maintained during $8 \mathrm{~h}$ of hypoxia or continued normoxia. The values of $V_{m}$ determined by the reference barrel of the double-barrel electrode ranged between -76 $\mathrm{mV}$ and $-84 \mathrm{mV}$, while the value of the OS was $>20 \mathrm{mV}$. This protocol had the advantage of allowing us to follow both $\mathrm{V}_{\mathrm{m}}$ and $\alpha_{\mathrm{K}}^{\mathrm{i}}$ in a single cell over time. The double-barrel electrodes, however, have the disadvantage of larger tip diameter and the use of $\mathrm{NaCl}$ as a filler in the reference barrel, both of which tend to lower the control measurements for $V_{m}$ and $\alpha_{k}^{i}$ compared with the single-barrel electrodes (17). During long-term maintained impalements there is inevitable signal drift due, in part, to change in tip potentials and variation in input bias current. Correction for drift was made with the assumption that this drift was linear over the 8-h period. The drift rate was $0.5-1.5 \mathrm{mV} / \mathrm{h}$.

To complement the experiments described above, we performed an additional set of experiments designed to further estimate the contribution of the $\mathrm{Na}-\mathrm{K}$ pump to $\mathrm{V}_{\mathrm{m}}$ (14). We inhibited the $\mathrm{Na}-\mathrm{K}$ pump by exposing the muscles to $0.1 \mathrm{mM}$ ouabain (Sigma Chemical Co., St. Louis, Mo.) after $8 \mathrm{~h}$ of hypoxia or normoxia and used the onset of an increase in $\alpha_{\mathrm{K}}^{\mathrm{e}}$ to mark the amount of depolarization due to pump inhibition. A double-barrel electrode was placed in the extracellular space as previously described $(19,22)$ to monitor change in $\alpha_{\mathrm{K}}^{\mathrm{e}}$, while a $3 \mathrm{M} \mathrm{KCl}$ electrode was placed intracellularly to monitor $V_{m}$ during ouabain exposure. The lefthand part of Fig. 3 shows the double-barrel electrode impaling the cell and advancing to the extracellular space. Displayed are the traces from the $V_{K}$ barrel of the doublebarrel electrode, the reference barrel $\left(V_{\text {ref }}\right)$, and their electronically subtracted difference signal $\left(V_{D}\right)$, which provides the substrate for the calculation of $\alpha_{\mathrm{K}}^{e}$ and which is so labeled. Also shown is a separately impaled $3 \mathrm{M} \mathrm{KCl}$ electrode that measures $V_{m}$ during ouabain exposure. After a few minutes in the extracellular space, $V_{K}, V_{\text {ref }}$, and $\alpha_{\mathrm{K}}^{\mathrm{e}}$ return to bath values. The electrodes were left in place for an additional $20 \mathrm{~min}$ after which the recorder gains were doubled and 0.1 $\mathrm{mM}$ ouabain added to the superfusate. We used the onset of an increase in $\alpha_{\mathrm{k}}^{\mathrm{e}}$ to distinguish the amount of depolarization in $V_{m}$, resulting solely from pump inhibition from that due to extracellular $\mathrm{K}^{+}$accumulation.

Data reduction. Data are expressed as means and standard errors of the mean. Student's $t$ test for paired and unpaired data was used to test for significance (23).

\section{RESULTS}

Table I shows the changes in $\mathrm{V}_{\mathrm{m}}, \alpha_{\mathrm{K}}^{\mathrm{i}}$ OS, and $\mathrm{APD}_{50}$ that occur during exposure to hypoxia. At the end of $3 \mathrm{~h}$ of exposure to severe hypoxia there were small changes in both $\mathrm{V}_{\mathrm{m}}$ and $\alpha_{\mathrm{k}}^{\mathrm{i}}$. $\mathrm{V}_{\mathrm{m}}$ decreased from $-89.3 \pm 0.7 \mathrm{mV}$ to $-84.6 \pm 0.5(P<0.01) \mathrm{mV}$ while $\alpha_{\mathrm{K}}^{\mathrm{i}}$ decreased from $104.6 \pm 4.8 \mathrm{mM}$ to $97.8 \pm 3.2 \mathrm{mM}$. Assuming that $\alpha_{\mathrm{k}}^{\mathrm{e}}$ equalled the potassium activity in the bulk solution $\left(\alpha_{\mathrm{K}}^{\circ}\right)$, the calculated potassium equilibrium potential $\left(\mathrm{E}_{\mathrm{K}}=\mathrm{RT} / \mathrm{F} \ln \alpha_{\mathrm{K}}^{\mathrm{o}} / \alpha_{\mathrm{K}}^{\mathrm{i}}\right)$ decreased from $-93.2 \pm 1.3 \mathrm{mV}$ at control to $-89.0 \pm 1.6 \mathrm{mV}$ at $3 \mathrm{~h}$, such that over this $3-\mathrm{h}$ period the difference between $V_{m}$ and $E_{K}$ was unchanged.

As seen in previous studies (1-3), there were significant changes in both the plateau phase, manifested by a shortening of the APD I). The shortening of the $A P D_{50}$ was seen in some experiments to begin within a few minutes of hypoxic exposure and decreased by a further $80 \%$ over $3 \mathrm{~h}$. The OS of the action potential decreased about $50 \%$ in 3 $\mathrm{h}$ from $37.7 \pm 1.6 \mathrm{mV}$ to $15.7 \pm 1.9 \mathrm{mV} \quad(P<0.01)$ (Table I).

After $3 \mathrm{~h}$ of severe hypoxia there was a small but definite depolarization in $V_{m}$, which in that respect is unlike most previous studies (1-3). However, the decline of $\mathrm{V}_{\mathrm{m}}$ was accompanied by a parallel decline in $E_{K}$. To test whether longer periods of exposure to hypoxia, similar to those employed by McDonald and MacLeod $(4,5)$, could stimulate the Na-K pump to hyperpolarize $V_{m}$ beyond $E_{K}$, we exposed muscles to hypoxic superfusate for $8 \mathrm{~h}$. In this protocol, rather 
TABLE I

$V_{m}, \alpha_{\mathrm{K}}^{\mathrm{i}}, A D P_{50}$ and $O S$ during $3 h$ of Hypoxia

\begin{tabular}{lccrr}
\hline & Control & $60 \mathrm{~min}$ & $120 \mathrm{~min}$ & \multicolumn{1}{c}{$180 \mathrm{~min}$} \\
\hline $\mathrm{V}_{\mathrm{m}}, m V$ & $-89.3 \pm 0.7$ & $-86.2 \pm 0.7$ & $-95.0 \pm 1.0$ & $-84.6 \pm 0.5^{\circ}$ \\
$\alpha_{\mathrm{K}}^{\mathrm{i}}, m M$ & $104.6 \pm 4.8$ & $101.5 \pm 4.9$ & $104.3 \pm 2.4$ & $97.8 \pm 3.2^{\circ}$ \\
$\mathrm{ADP}$ & \\
$\mathrm{OS}, m s$ & $222.8 \pm 12.1$ & $117.0 \pm 10.2$ & $39.2 \pm 4.2$ & $24.0 \pm 4.2^{\circ}$ \\
$\mathrm{OS}, m$ & $37.7 \pm 1.6$ & $22.7 \pm 1.1$ & $21.8 \pm 1.9$ & $15.7 \pm 1.9^{\circ}$ \\
\hline
\end{tabular}

Data represent mean $\pm \mathrm{SE} ; \boldsymbol{n}=10$.

- $P<0.01$.

than using multiple and separate impalements to measure $V_{m}$ and $V_{K}$, we used a double-barrel electrode impaled in a single cell over the experimental period. This afforded us continuous measurements of $\alpha_{\mathrm{k}}^{\mathrm{i}}$ and $V_{m}$ in a given cell over time and allowed us to confirm the changes seen in $V_{m}$ and $\alpha_{k}^{i}$ by the technique of multiple electrode impalements. Fig. 2 illustrates a representative tracing of a continuous impalement with a double-barrel electrode and shows the depolarization of $\mathrm{V}_{\mathrm{m}}$ and the decline in $\alpha_{\mathrm{k}}^{\mathrm{i}}$ over $8 \mathrm{~h}$ of hypoxia.

After the $8 \mathrm{~h}$ there were significant declines in the values of $\mathrm{V}_{\mathrm{m}}$ and $\alpha_{\mathrm{K}}^{\mathrm{i}}$ (Table II). $\mathrm{V}_{\mathrm{m}}$ depolarized from $-81.4 \pm 0.8 \mathrm{mV}$ to $-71.4 \pm 0.6 \mathrm{mV}(P<0.01)$ while $\alpha_{\mathrm{K}}^{1}$ decreased from $96.1 \pm 4.1 \mathrm{mM}$ to $65.1 \pm 2.9 \mathrm{mM}$ $(P<0.01)$. Over this period the calculated $E_{K}$ decreased from $-92.3 \pm 1.2 \mathrm{mV}$ to $-83.6 \pm 0.5(P<0.05)$. Although there were significant decreases in $V_{m}$ and $E_{K}$, the rates of decline in $V_{m}$ and $E_{K}$ were not different, suggesting that the relationship between $V_{m}$ and $E_{K}$ was unchanged.

As can be seen from Tables I and II, the control values for $V_{m}$ and $\alpha_{k}^{i}$ obtained with the double-barrel electrode were somewhat lower than those obtained by averaging multiple impalements with single-barrel electrodes. As demonstrated previously (17), this represents differences in tip diameter and in the use of $1.0 \mathrm{M} \mathrm{NaCl}$ as a filler in the reference barrel of the double-barrel electrode, as compared with $3 \mathrm{M} \mathrm{KCl}$ in a single-barrel reference electrode. Using double-barrel electrodes it was noted that after the first $3 \mathrm{~h}$ of hypoxia in the $8 \mathrm{~h}$ protocol, $\mathrm{V}_{\mathrm{m}}$ declined to $-76.9 \pm 1.0$ $\mathrm{mV}$ and $\alpha_{\mathrm{k}}^{\mathrm{i}}$ decreased to $84.5 \pm 3.9 \mathrm{mM}$. These data suggest that, although the control values for the singleand double-barrel electrodes are somewhat different, both techniques record similar rates of change in $V_{m}$ and $\alpha_{\mathrm{k}}^{\mathrm{i}}$ during hypoxia, and because one technique samples many cells over time while the other records from one cell over time, they form a strong complement.

The parallel decline in $\mathrm{V}_{\mathrm{m}}$ and $\mathrm{E}_{\mathrm{K}}$ after $8 \mathrm{~h}$ of hypoxia stands in contrast to the findings after $8 \mathrm{~h}$ of control normoxic superfusion. During this control experiment there were no significant changes in $V_{m}$, $\alpha_{\mathrm{K}}^{\mathrm{i}}$, or $\mathrm{E}_{\mathrm{K}}$ (Table II), and the relationship between $\mathrm{V}_{\mathrm{m}}$ and $E_{K}$ was unchanged.

As a corroborative experiment we inhibited the pump with $0.1 \mathrm{mM}$ ouabain after the $8 \mathrm{~h}$ of hypoxia or normoxia to further test the contribution of the $\mathrm{Na}$ $K$ pump to $V_{m}$ (14). Using a double-barrel electrode placed in the extracellular space, we detected an increase in $\alpha_{\mathrm{K}}^{\mathrm{e}}$ after the normoxic muscle depolarized by $4.8 \pm 1.1 \mathrm{mV}$ (Fig. 3). In the normoxic muscle this detection was noted after $2.8 \pm 0.1 \mathrm{~min}$ of ouabain exposure. In the hypoxic muscle, the muscle depolarized by $8.4 \pm 2.2 \mathrm{mV}$ before an increase in $\alpha_{\mathrm{K}}^{\mathrm{e}}$ was detected. In these muscles the increase in $\alpha_{\mathrm{k}}^{\mathrm{e}}$ was detected after $3.4 \pm 0.2 \mathrm{~min}$ of ouabain exposure, which was a longer period than after normoxia $(P<0.05)$.

\section{DISCUSSION}

Our data do not support the hypothesis that electrogenic Na-K pumping maintains (up to $30 \mathrm{mV}$ ) $V_{m}$ during prolonged hypoxia. Rather, these data suggest that during oxygen deprivation the resting membrane potential of ventricular muscle continues to be primarily determined by the passive distribution of potassium and that the contribution of the electrogenic $\mathrm{Na}-\mathrm{K}$

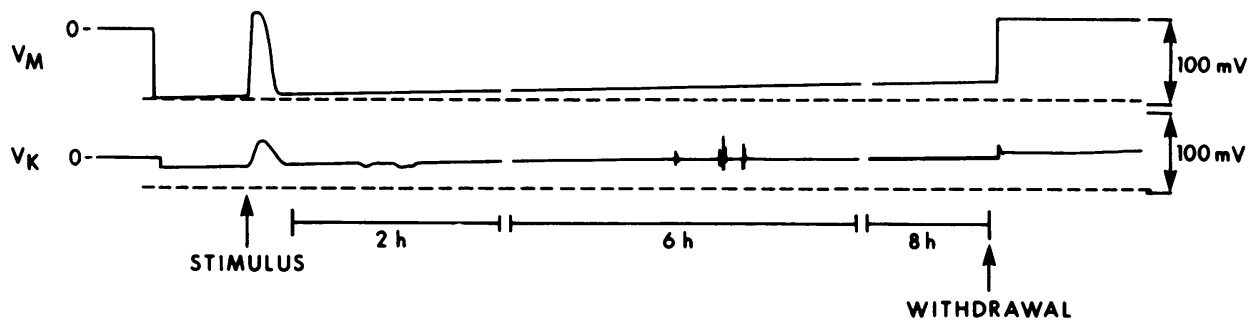

FigURE 2 Decrease in $V_{m}$ and $V_{K}$ measured with a double-barrel electrode over the 8-h period. A stimulus to demonstrate impalement is seen on the left-hand part of the trace. The top of the action potential from the reference barrel has been abbreviated at this scale to focus on resting potential. In this muscle, $V_{m}$ depolarized from $-82 \mathrm{mV}$ to $-73 \mathrm{mV}$, while $\alpha_{\mathrm{K}}^{\mathrm{i}}$ decreased from $94 \mathrm{mM}$ to $67 \mathrm{mM}$. The zero drift in this study was $\sim 0.5 \mathrm{mV} / \mathrm{h}$. 
TABLE II

$V_{m}, \alpha_{\mathrm{K}}^{\mathrm{i}}$, and $E_{\mathrm{K}}$ over $8 h$ of Hypoxia or Normoxia

\begin{tabular}{|c|c|c|c|c|c|}
\hline & Control & $2 \mathrm{~h}$ & $4 \mathrm{~h}$ & $6 \mathrm{~h}$ & $8 \mathrm{~h}$ \\
\hline \multicolumn{6}{|c|}{ Hypoxia $(n=8)$} \\
\hline $\mathrm{V}_{\mathrm{m}}, m V$ & $-81.4 \pm 0.8$ & $-78.5 \pm 0.9$ & $-76.3 \pm 0.9$ & $-73.8 \pm 0.9$ & $-71.4 \pm 0.6^{\circ}$ \\
\hline$\alpha_{\mathbf{K}}^{i}, m M$ & $96.1 \pm 4.1$ & $85.2 \pm 4.9$ & $82.8 \pm 4.5$ & $73.4 \pm 3.7$ & $65.1 \pm 2.9^{\circ}$ \\
\hline $\mathrm{E}_{\mathbf{K}}, m \boldsymbol{V}$ & $-92.3 \pm 1.2$ & $-87.1 \pm 1.4$ & $-87.1 \pm 1.1$ & $-85.2 \pm 1.3$ & $-83.6 \pm 0.5 \ddagger$ \\
\hline \multicolumn{6}{|c|}{ Normoxia $(n=6)$} \\
\hline $\mathbf{V}_{m}, m V$ & $-79.5 \pm 0.9$ & $-82.0 \pm 0.6$ & $-75.8 \pm 1.0$ & $-79.0 \pm 0.2$ & $-80.1 \pm 0.9$ \\
\hline$\alpha_{\mathrm{K}}^{\mathrm{i}}, m M$ & $95.8 \pm 6.0$ & $97.1 \pm 4.1$ & $91.4 \pm 3.5$ & $92.8 \pm 6.6$ & $97.0 \pm 6.6$ \\
\hline $\mathbf{E}_{\mathbf{K}}, m V$ & $-92.3 \pm 1.6$ & $-95.0 \pm 1.7$ & $-90.8 \pm 1.7$ & $-90.8 \pm 1.6$ & $-92.3 \pm 1.3$ \\
\hline
\end{tabular}

Data represent mean $\pm \mathrm{SE}$.

- $P<0.01$.

t $P<0.05$.

pump changes little, if at all. Our data are in agreement with some preliminary data of Weir (24) but differ somewhat from the data of Baumgarten et al. (25) who showed evidence of muscle heterogenicity during hypoxia. The potassium equilibrium potential, $\mathrm{E}_{\mathbf{K}}$, that we calculated from the measured $\alpha_{\mathbf{K}}^{\mathrm{i}}$ and the bulk $\alpha_{\mathrm{K}}^{\circ}$ during prolonged hypoxia parallels the decline in the measured $V_{m}$. The absolute value of $E_{k}$, however, must be interpreted with caution, as small increases in $\alpha_{\mathrm{K}}^{\mathrm{e}}$ in the transverse tubules or clefts may tend to decrease $E_{\mathrm{k}}$. Cleft $\alpha_{\mathrm{k}}^{\mathrm{e}}$ would uniformly have to increase by over $50 \%$ for $V_{m}$ to be more negative than $E_{K}$, and this seems unlikely particularly with the use of Gadsby's (15) fast flow bath. We found no evidence of a relative hyperpolarization of $V_{m}$ beyond $E_{K}$ and thus cannot support the concept that stimulated electrogenic $\mathrm{Na}-\mathrm{K}$ pumping maintains $\mathrm{V}_{\mathrm{m}}$ during hypoxia in the degree previously suggested.

Our data also demonstrate that severe hypoxia will cause significant depolarization. The lack of significant depolarization described in previous studies may have been due to less severe reduction of $\mathrm{pO}_{2}(1-3)$. As demonstrated by Schubert (26) and also by Grunewald (27), the normoxic $\mathrm{pO}_{2}$ in myocardial tissue may range as low as $20-30 \mathrm{~mm} \mathrm{Hg}$. The $\mathrm{pO}_{2}$ sampled at the muscle surface in our experiments was substantially lower and probably explains the decrease in $V_{m}$ seen in our studies.

Central to our hypothesis is the observation that the decrease in $\alpha_{\mathrm{K}}^{\mathrm{i}}$ after prolonged hypoxia is much less than the decrease in $[\mathrm{K}]_{\mathrm{i}}$ reported by McDonald and MacLeod $(4,5)$. The discrepancy in the decrease in $\alpha_{\mathrm{K}}^{\mathrm{i}}$ that we observed and the decrease in $[\mathrm{K}]_{\mathrm{i}}$ reported by McDonald and MacLeod $(4,5)$ during exposure to hypoxia may be attributed to at least three mechanisms. First, as noted by Page and Storm (7), the determination of $[K]_{i}$ is done on whole muscle bundles where, depending on thickness, there may be large $[\mathrm{K}]$ gradients between the cells in the center and cells on the surface. This would tend to substantially lower the average $K$ concentration made on the whole bundle. Because of the presence of these potassium gradients, it cannot be assumed that the potassium content of a surface cell, where $V_{m}$ is measured, is the same as the potassium content derived from analysis of the total muscle bundle. Our measurements of $\alpha_{\mathrm{k}}^{\mathrm{i}}$, particularly as followed in a given cell, were obtained from cells on the surface of the preparation, which are in contact with rapidly exchanging perfusate and where gradients would tend to be less. Second, the determination of $[\mathrm{K}]_{\mathrm{i}}$ requires estimation of the intracellular volume, usually determined with the use of extracellular markers. These may be inaccurate after prolonged hypoxia because of changes in membrane permeability, as for instance those suggested by the morphological studies of Ganote or Hatt $(28,29)$. The determination of $\alpha_{\mathrm{k}}^{\mathrm{i}}$ with potassium-selective electrodes requires no estimate of cell volume. Third, hypoxia may cause a shift in the $\mathrm{K}^{+}$activity coefficient $\left(\gamma_{\mathrm{K}}\right)$, the ratio of $\alpha_{\mathrm{K}}^{\mathrm{i}}$ to $[\mathrm{K}]_{\mathrm{i}}$. Changes in the activity coefficient were reported by Lee and Armstrong (30) when skeletal muscle fibers were loaded with sodium and it is conceivable that the sodium loading, which is thought to occur in hypoxia, may also affect $\gamma_{\mathbf{k}}$.

Regardless of the mechanism of the low $[K]_{i}$, it is difficult to accept that $V_{m}$ could hyperpolarize beyond $E_{K}$ by $30-40 \mathrm{mV}$ for such prolonged periods under such hypoxic stress. This is so because the new electrochemical driving force for $\mathrm{K}^{+}\left(\mathrm{V}_{\mathrm{m}}-\mathrm{E}_{\mathrm{K}}\right)$ would tend to continually drive $\mathrm{K}^{+}$into the cell and drive $\mathrm{E}_{\mathrm{K}}$ toward $V_{m}$. The maintenance of this reversal of driving force would, in the steady-state, actually require active extrusion of potassium, which has not been described.

As a corroborative experiment we used an increase 


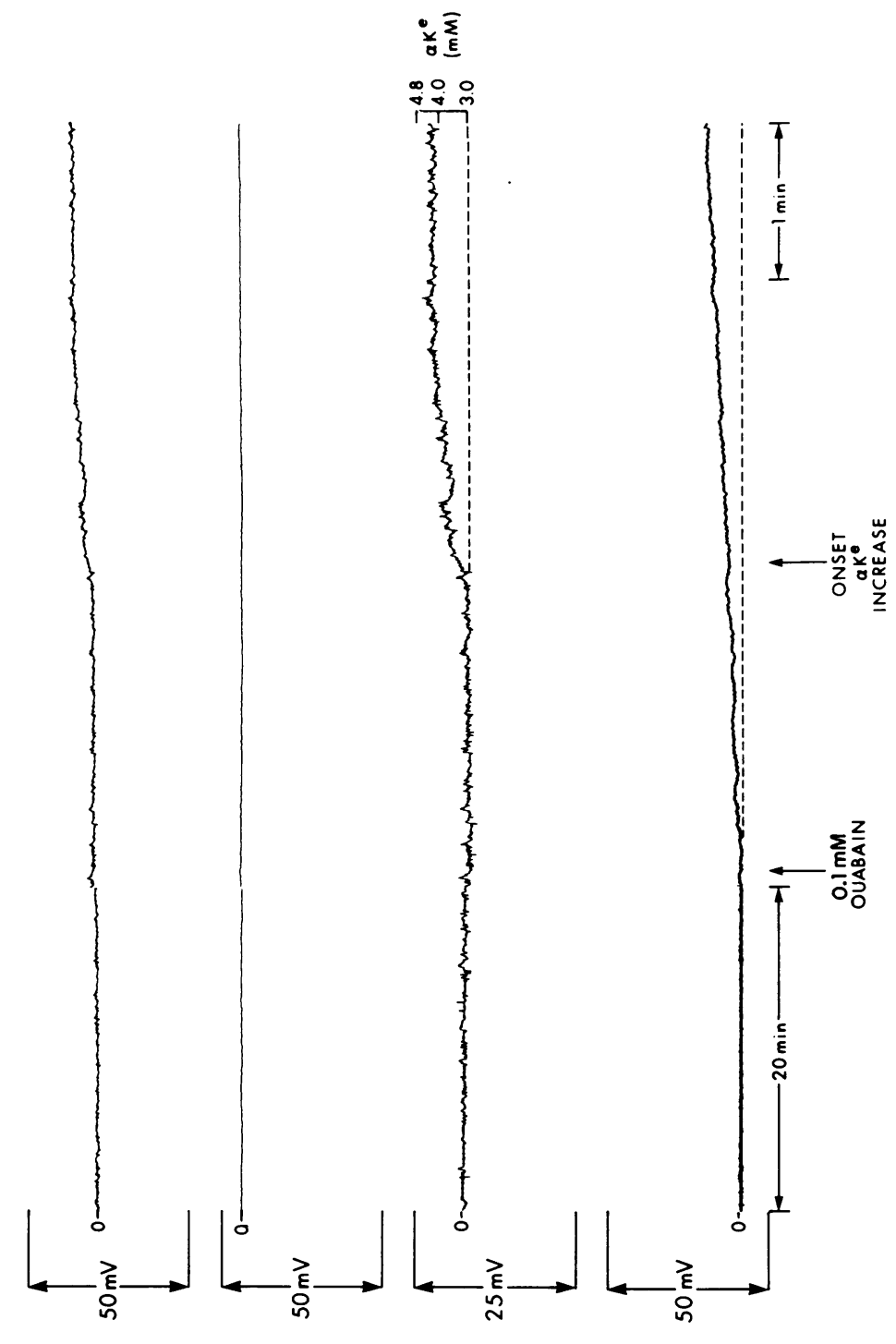

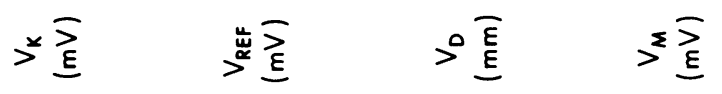

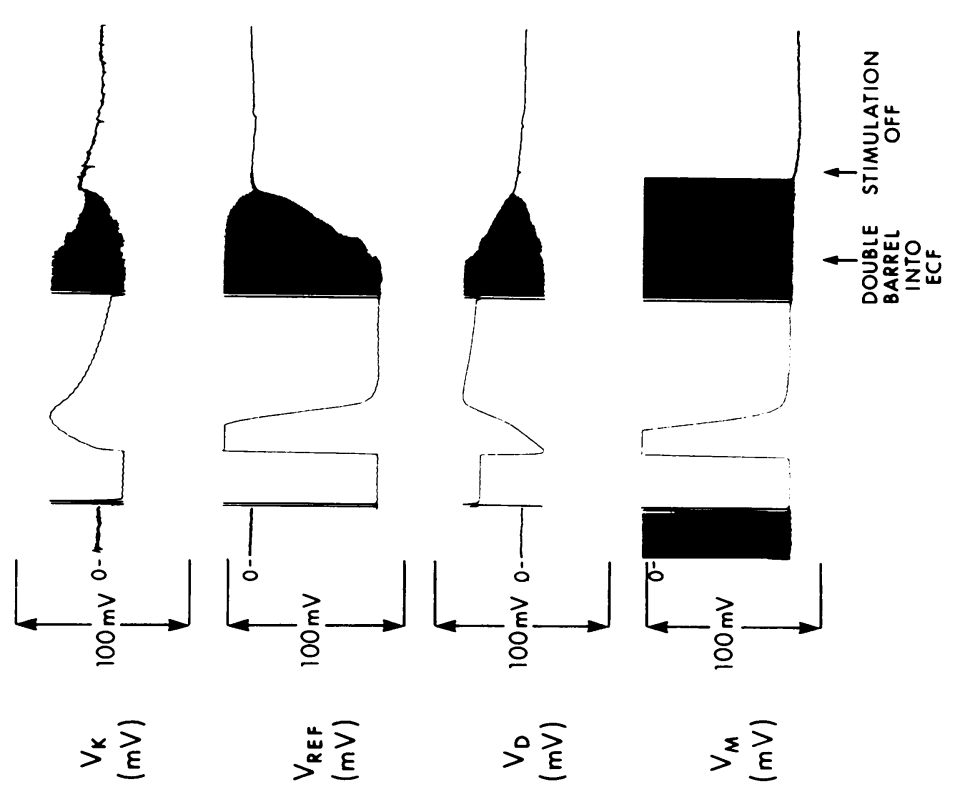

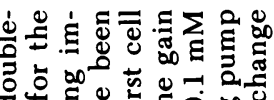

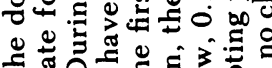

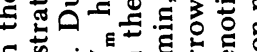
ह क के वे

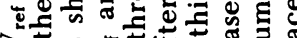
$>\cong . \tilde{0}$

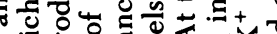

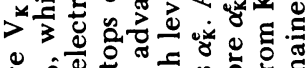

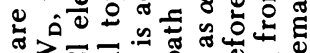

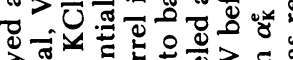

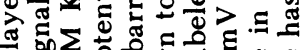
क्षे

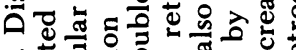

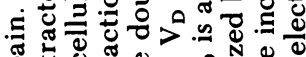

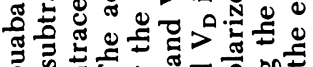
के

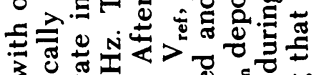

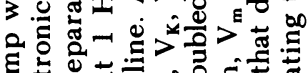
है⿴囗十⿻

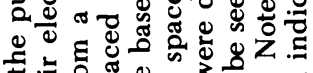

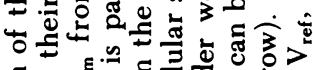
ธ등>

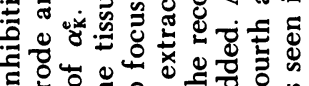

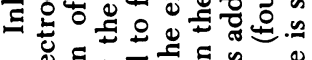

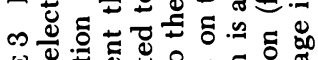

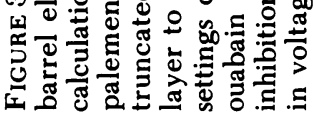


in $\alpha_{\mathrm{K}}^{\mathrm{e}}$ during exposure to $0.1 \mathrm{mM}$ ouabain as a marker for the amount of depolarization due solely to pump inhibition (17). Similar types of measurements of $\alpha_{\mathbf{K}}^{\mathrm{e}}$ using double-barrel potassium-selective electrodes have been reported by Kunze (19) in response to rapid pacing and by Kline and Morad (22) who reported changes in $\alpha_{\mathrm{K}}^{\mathrm{e}}$ during a single action potential. After prolonged normoxia, this value was $4.8 \pm 1.1 \mathrm{mV}$, which is in accord with other estimates of pump contribution to $V_{m}$ (31). After prolonged hypoxia this value was $8.1 \pm 2.2$ $\mathrm{mV}$, which is somewhat higher than control but still considerably less than that reported by McDonald and MacLeod $(4,5)$. In fact, it is likely that this estimate after hypoxia is spuriously high. The double-barrel electrode almost certainly damages the hypoxic tissue and distorts the cleft to a greater extent than in normoxia. If there is poor healing-over in hypoxia, this would leave a larger space for the same of less $\mathrm{K}$ extrusion and makes this method a less sensitive index of change in pump rate during hypoxia. The observation that the time between ouabain exposure and the detection of an increase in $\alpha_{\mathbf{K}}^{e}$ in hypoxia was greater than during normoxia is also consistent with the double-barrel electrode causing a greater distortion of the space. Because of possible changes in sodium or potassium conductances, these estimates probably set an upper limit for pump contribution to $\mathrm{V}_{\mathrm{m}}$. Nonetheless, these corroborative experiments will set the pump contribution to $V_{m}$ considerably lower after hypoxia than previously stated.

Changes seen in this study in the duration of the action potential are consistent with those previously described $(1,2,5)$. Our experiments were not designed to shed light on the controversy as to whether the plateau shortening during exposure to hypoxia represents an outward, presumably $\mathrm{K}^{+}(32)$ current, or a decrease in the slow inward current (33), but they merely serve as the basis for comparison with other studies.

With the degree of hypoxia seen in these studies, there was also a remarkable decrease in the OS, $\sim 50 \%$ in $3 \mathrm{~h}$. This would be compatible with either changes in $\mathrm{g}_{\mathrm{Na}}$ or $\mathrm{E}_{\mathrm{Na}}$. The latter almost certainly decreases as intracellular sodium activity increases. However, as noted by Coraboeuf (34), the guinea pig papillary muscle may be a poor model for correlations between $\mathrm{E}_{\mathrm{Na}}$ and OS.

In summary, this study demonstrates that $\alpha_{\mathrm{K}}^{\mathrm{i}}$ decreases much less during prolonged hypoxia than $[K]_{i}$. The relatively higher value of $\alpha_{\mathrm{k}}^{\mathrm{i}}$ yields a calculated $E_{K}$ from which the measured $V_{m}$ does not hyperpolarize. The hypothesis that electrogenic $\mathrm{Na}-\mathrm{K}$ pumping maintains $V_{m}$ during hypoxia is not supported. Rather, these data suggest that during severe hypoxia the resting membrane potential continues to be primarily determined by the passive distribution of potassium.

\section{ACKNOWLEDGMENTS}

Special thanks go to Dr. David J. Browning for his careful review of the manuscript; to Dr. Joseph C. Greenfield, Jr. for his continuing support; to Amalia B. S. Hutchison for her technical assistance, and to Renate Wend for typing the manuscript.

This work was supported in part by U. S. Public Health Service grants HL 19216, 17670, and 07101, and by a Research Career Development Award (1-KO4-HL-00268) to Dr. Strauss.

\section{REFERENCES}

1. Trautwein, W., U. Gottstein, and J. Dudel. 1954. Aktionsstrom der Myokardfaser im Sauerstoffmangel. Pflügers Arch. Eur. Physiol. 260: 40-60.

2. Coraboeuf, E., Y. M. Gargouil, J. Laplaud et A. Desplaces. 1958. Action de l'anoxie sur les potentiels électriques des cellules cardiaques de mammifères activés et inertes (tissue ventriculaire isolé de cobaye). C. R. Acad. Sci. (D) (Paris). 246: 3100-3103.

3. MacLeod, D. P., and E. E. Daniel. 1965. Influence of glucose on the transmembrane action potential of anoxic papillary muscle. J. Gen. Physiol. 48: 887-899.

4. McDonald, T. F., and D. P. MacLeod. 1971. Maintenance of resting potential in anoxic guinea pig ventricular muscle. Electrogenic sodium pumping. Science (Wash., D. C.). 172: 570-572.

5. McDonald, T. F., and D. P. MacLeod. 1973. Metabolism and the electrical activity of anoxic ventricular muscle. J. Physiol. (Lond.). 229: 559-582.

6. Page, E., R. J. Goerke, and S. R. Storm. 1964. Cat heart muscle in vitro. V. Inhibition of transport in quiescent muscles. J. Gen. Physiol. 47: 531-547.

7. Page, E., and S. R. Storm. 1965. Cat heart muscle in vitro. VIII. Active transport of sodium in papillary muscles. J. Gen. Physiol. 48: 957-972.

8. Vassalle, M. 1970. Electrogenic suppression of automaticity in sheep and dog Purkinje fibers. Circ. Res. 27: 361-377.

9. Thomas, R. C. 1972. Electrogenic sodium pump in nerve and muscle cells. Physiol. Rev. 52: 538-594.

10. Carmeliet, E. 1978. Cardiac transmembrane potentials and metabolism. Circ. Res. 42: 577-587.

11. Walker, J. L., and R. O. Ladle. 1973. Frog heart intracellular potassium activities measured with potassium microelectrodes. Am. J. Physiol. 225: 263-267.

12. Lee, C. O., and H. Fozzard. 1977. Activities of potassium and sodium ions in rabbit heart muscle. J. Gen. Physiol. 65: 695-708.

13. Miura, D. S., B. F. Hoffman, and M. R. Rosen. 1977. The effect of extracellular potassium on the intracellular potassium ion activity and transmembrane potentials of beating canine cardiac Purkinje fibers. J. Gen. Physiol. 69: 463-474.

14. Trantham, J., D. J. Browning, A. O. Grant, A. G. Wallace, and H. C. Strauss. 1981. The coupling ratio of the $\mathrm{Na}-\mathrm{K}$ exchange pump in mammalian cardiac tissue. Fed. Proc. 40: 392 .

15. Gadsby, D. C. 1980. Activation of electrogenic $\mathrm{Na}^{+} / \mathrm{K}^{+}$ exchange by extracellular $\mathrm{K}^{+}$in canine cardiac Purkinje fibers. Proc. Natl. Acad. Sci. U.S.A. 77: 4035-4039.

16. Robinson, R. A., and R. H. Stokes. 1968. Electrolyte Solutions. Butterworths Publishers Inc., London, England. 
17. Browning, D. J., and H. C. Strauss, 1981. Effects of stimulation frequency on potassium activity and cell volume in cardiac tissue. Am. J. Physiol. (Cell Physiol.). 240: C39-C55.

18. Browning, D. J., T. Guarnieri, and H. C. Strauss. 1981. Ouabain effects on intracellular potassium activity and contractile force in cat papillary muscle. J. Clin. Invest. 68: 942-956.

19. Kunze, D. L. 1977. Rate-dependent changes in extracellular potassium in rabbit atrium. Circ. Res. 41: 122127.

20. Walker, J. L., and H. M. Brown. 1977. Intracellular ionic activity measurements in nerve and muscle. Physiol. Rev. 57: 729-788.

21. Nikolskii, B. P. 1937. The theory of the glass electrode. Zh. Fiziol. Khim. 10: 495-503.

22. Kline, R. P., and M. Morad. 1977. Potassium efflux in heart muscle during activity: extracellular accumulation and its implications. J. Physiol. (Lond.). 280: 537-558.

23. Snedecor, G. W., and W. G. Cochran. 1972. Statistical Methods. Iowa State University Press, Ames, Iowa.

24. Weir, W. G. 1978. Ionic currents and intracellular potassium in hypoxic cells. Biophys. J. 21: 166a.

25. Baumgarten C. M., C. J. Cohen, and T. F. McDonald. 1981. Heterogeneity of intracellular potassium activity and membrane potential in hypoxic guinea pig ventricle. Circ. Res. 49: 1181-1189.

26. Schubert, R. W., W. J. Whalen, and P. Nair. Myocardial
$\mathrm{pO}_{2}$ distribution: relationship to coronary autoregulation. Am. J. Physiol. 234: H361-H370.

27. Grunewald, W. A., and W. Sowa. 1978. Distribution of the myocardial tissue $\mathrm{pO}_{2}$ in the rat and inhomogeneity of the coronary bed. Pfluegers Arch. Eur. Physiol. 379: 57-66.

28. Ganote, C. E., R. Seabra-Gomes, W. G. Naylor, and R. B. Jennings. 1975. Irreversible myocardial injury in anoxic perfused rat hearts. Am. J. Pathol. 80: 419-450.

29. Hatt, P. Y., and J. Moravek. 1971. Acute hypoxia of the myocardium. Cardiology. 56: 73-84.

30. Lee, C. O., and W. McD. Armstrong. 1974. State and distribution of potassium and sodium ions in frog skeletal muscle. J. Membr. Biol. 15: 331-362.

31. Ruiz-Ceretti, E., A. Nguyen-Thi, O. F. Schanne, and J. P. Caille. 1981. An electrogenic component of resting potential in rabbit ventricular muscle. Am. J. Physiol. 240: C28-C34.

32. Vleugels, A., J. Vereecke, and E. Carmeliet. 1980. Ionic currents during hypoxia in voltage clamped cat ventricular muscle. Circ. Res. 47: 501-508.

33. Hunter, E. G., T. F. McDonald, and D. P. MacLeod. 1972. Metabolic depression and myocardial potassium. Pfluegers Arch. Eur. Physiol. 335: 266-278.

34. Coraboeuf, E., et M. Otsuka. 1956. L'action des solutions hyposodiques sur les potentiels cellulaires de tissu cardiaque de mammifères. C. R. Acad. Sci. (D) (Paris). 243: 411-444. 